\title{
Hilsa Fishers of Ramgati, Lakshmipur, Bangladesh: An Overview of Socio- Economic and Livelihood Context
}

\author{
Muhammad Enayet Ullah Rana ${ }^{1}$, Abdus Salam¹, Shahriar Nazrul KM²${ }^{\star}$ and Md. Monjurul Hasan ${ }^{3}$ \\ ${ }^{1}$ Department of Aquaculture, Bangladesh Agricultural University, Mymensingh, Bangladesh \\ ${ }^{2}$ Department of Fisheries, Marine Fisheries Survey Management Unit, Ministry of Fisheries and Livestock, Bangladesh
}

${ }^{3}$ Bangladesh Fisheries Research Institute, Riverine Station, Chandpur, Bangladesh

\begin{abstract}
The present investigation was carried out to assess the socio-economic and livelihood status of the hilsa (Tenualosa ilisha) fishermen of the river Meghna in Ramgati upazila (sub-district) under Lakshmipur district from December 2015 to May 2016. Pertinent data were collected from randomly selected 150 hilsa fishermen by personal interview with a structured questionnaire, focus group discussion and, data were crosschecked with the key informants. Data interpretation showed that the maximum number of fishers $(33 \%)$ belonged to the age group of 31 to 40 years. Most of the fishers belonged to the joint family with average family members (7) higher than the national average. In addition, most of the participants (49\%) can only sign followed by illiterate (24\%) and only few fishers passed primary $(20 \%)$ and secondary $(7 \%)$ level of education. Although they are fishing round the year, vegetables were the most common food item consumed by the fishers' family. Majority of the fishers (67\%) worked on another fishermen's boat as labour. The highest number (44\%) of the fishers' annual income ranged between 21,000 and 40,000 BDT where highest income was more than 100,000 BDT. About $93 \%$ of the fishermen depended on loan to run the fishing and among them $33 \%$ depended on Mahajon and $24 \%$ on Aratdar. Almost all the fishers (91\%) mentioned that piracy was the major problem and, $53 \%$ and $89 \%$ reported both dadon and market controlled by Aratder/bapari respectively as the main constraints in their business. To safeguard the livelihood of the fishermen, the government, donor agencies and NGOs should come forward to provide adult education, loan without or minimum interest and set criteria for the Aratder/bapari so that they can't harass the fishers during fish selling.
\end{abstract}

Keywords: Hilsa; Tenualosa ilisha; Meghna river; Livelihood; Bangladesh

\section{Introduction}

In Bangladesh, hilsa (Tenualosa ilisha) occurs in inland, marine and coastal waters and is harvested throughout the year. Hilsa has the highest contribution $(>10 \%)$ to the fish production of Bangladesh as a single species and in 2015-16 the contribution was 0.395 million metric ton [1]. It is considered as the national fish of the country and contributes to the national economy, employment and export. An estimated 0.46 million people are engaged in hilsa and jatka fishing [2]. About 2 million people are directly or indirectly involved with the catching and trading of Hilsa fish in the country for their livelihood [3].

Meghna is one of the largest rivers of the country interconnected by various channels to form one continuous sheet of water in the rainy season. It covers an area of about 900 hectares of Ramgati upazila and an approximately 25,500 fishermen in this area are dependent on the riverine fish for their livelihood and protein supply. The place is blessed with very resourceful water bodies of Meghna, full of riverine fisheries resources, major catches are hilsa, poa, icha, taposhi/rickshaw, bata, pangas etc [4]. A fairly huge number of different types and forms of gears have been operated in the Meghna river to exploit wild fishes since time immemorial. The intensity of use of any form of gear in a river is dependent on the intensity of target fish population available in the river, some of the gears are selective for a particular species, whereas other account for a number of species caught during operation giving multi-species nature of the fishing [5]. Some nets are specially meant for catching species of fish while others are used for netting any type of fish that comes on the way. The choice of nets also depends upon the area of operation and varies from place to place even in same river [6].

Fishers are engaged throughout the year in the hilsa fishery in Bangladesh. The people do not possess any land for crop cultivation so the rivers and hilsa are their only means of survival. Ignoring the intense heat of the sun, the lack of security and safety measures during monsoons and tidal waves, and having little or no food during fishing, these fishers struggle for their livelihood. Some fishers are happy with a catch of just one average sized fish per day, as it provides them with money needed to feed their family or repay a boat loan. Most of the fishers are so poor that they are unable to upgrade their boats.

No research work is conducted yet about the lives and livelihood of the hilsa fishermen in Ramgati region. Therefore, the present study was carried out to assess the present socio-economic and livelihood condition of the hilsa fishermen of Ramgati upazila along the Meghna river.

\section{Materials and Methods}

\section{Location of the study area}

In the present study Ramgati upazila (sub-district) of Lakshmipur district was selected as the study area that represents more or less common picture of the total hilsa fishermen community. The main criteria behind the selection of the study area are:

a) The suitability of the area to fulfil the objectives of the study,

*Corresponding author: Shahriar Nazrul KM, Department of Fisheries, Marine Fisheries Survey Management Unit, Ministry of Fisheries and Livestock Bangladesh, Tel: +8801717162260; E-mail: shahriar_rimon@yahoo.com

Received May 07, 2018; Accepted July 07, 2018; Published July 13, 2018

Citation: Rana MEU, Salam A, Shahriar Nazrul KM, Hasan M (2018) Hilsa Fishers of Ramgati, Lakshmipur, Bangladesh: An Overview of Socio-Economic and Livelihood Context. J Aquac Res Development 9: 541. doi: 10.4172/2155-9546.1000541

Copyright: (c) 2018 Rana MEU, et al. This is an open-access article distributed under the terms of the Creative Commons Attribution License, which permits unrestricted use, distribution, and reproduction in any medium, provided the original author and source are credited. 
Citation: Rana MEU, Salam A, Shahriar Nazrul KM, Hasan M (2018) Hilsa Fishers of Ramgati, Lakshmipur, Bangladesh: An Overview of Socio-Economic and Livelihood Context. J Aquac Res Development 9: 541. doi: 10.4172/2155-9546.1000541

Page 2 of 5

b) Concentration of different types of fishermen and

c) Good communication system.

The upazila is situated on the bank of the Meghna river and under Lakshmipur district of Chittagong division, Bangladesh. It is located between $22^{\circ} 52^{\prime}$ and $22^{\circ} 90^{\prime}$ North latitudes and in between $90^{\circ} 47^{\prime}$ and $91^{\circ} 01^{\prime}$ East longitudes. It has an area of $291.82 \mathrm{sq} \mathrm{km}$.

\section{Study duration}

The study was conducted for a period of six months from December 2015 to May 2016 to get the ideal picture of the basic profile of fishermen of the Meghna river.

\section{Sample size and sampling procedure}

The major focus of the study was the fishermen and fisher folk involved in fishing and fish marketing of the Meghna river. A total of 150 hilsa fishermen were selected equally from three different areas (Ramgati Bazar, Char Algi and Char Alexander) adjacent to the Meghna river by using random sampling. To achieve the objective of the study a comprehensive interview schedule of structured questionnaire was used to collect data through both primary (questionnaire interviews, focus group discussion) and secondary sources (cross-check interviews).

\section{Data processing and analysis}

Collected data were summarized and scrutinized carefully and recorded. Data collected in local unit were altered into standard unit in order to lessen miscalculation. Collected data were analyzed by computer software Microsoft Excel version 2010.

\section{Results and Discussion}

\section{Fishermen types}

Fishes are caught throughout the year by a large number of fishermen around the Meghna river area. Hilsa fishermen can be categorized into two groups on the basis of standard practice: professional fishermen (depend on fishing almost year-round for their livelihood) and seasonal fishermen (catch fish only a part of the year as a source of income and keep them engaged in other activities in other time). In the present study it was found that most of the hilsa fishermen were professional (91\%), followed by seasonal hilsa fishermen which was only $9 \%$ (Table 1). In a study of Jamuna river at Dewangonj upazila, Akram found that $60 \%$ of the fishermen were professional, $30 \%$ were seasonal and the rest $10 \%$ were subsistence [7].

\section{Age and sex of the respondents}

$22 \%$ of fishermen of the study area were 11 to 20 years old, $22 \%$ were 21 to 30 years old, $33 \%$ were 31 to 40 years old, $16 \%$ were 41 to 50 years old and $7 \%$ were more than 50 -years-old (Table 1). There was no female fisherman found in any of the study area. Bhaumik and Saha reported the age group of fishermen of Sunderbans varied between 20 to 70 years [8]. In a similar study, Minar et al., found that most of the fishermen belonged to the age groups of 31 to 40 years (56\%) in the Kirtonkhola river near to the Barisal town [9].

\section{Family types and members}

The family functions as a unit for income generation, consumption, reproduction and social interaction. 91\% fishermen families were jointed, and $9 \%$ families were nuclear in the present study area (Table 1). The average family members were found 7 in each household. Considering all the members of the respondents' family average 3 were found male and 4 were female members. Minar et al., found that $86 \%$ of fishermen family was jointed and $16 \%$ of family was nuclear and, most of the fishermen family was represented by 5 to 6 members in the Kirtonkhola river [9].

\begin{tabular}{|c|c|c|}
\hline Parameters & Fishermen number & Frequency $(\%)$ \\
\hline \multicolumn{3}{|c|}{ Fishermen category } \\
\hline Professional & 137 & 91 \\
\hline Seasonal & 13 & 9 \\
\hline \multicolumn{3}{|l|}{ Age (Years) } \\
\hline $11-20$ & 33 & 22 \\
\hline $21-30$ & 33 & 22 \\
\hline $31-40$ & 50 & 33 \\
\hline $41-50$ & 24 & 16 \\
\hline$>50$ & 11 & 7 \\
\hline \multicolumn{3}{|l|}{ Sex } \\
\hline Male & 150 & 100 \\
\hline Female & 0 & 0 \\
\hline \multicolumn{3}{|l|}{ Family type } \\
\hline Joint & 137 & 91 \\
\hline Nuclear & 13 & 9 \\
\hline \multicolumn{3}{|l|}{ Educational status } \\
\hline No education & 36 & 24 \\
\hline Can only sign & 74 & 49 \\
\hline Primary level & 30 & 20 \\
\hline Secondary level & 11 & 7 \\
\hline
\end{tabular}

Table 1: Socio-demographic information of the hilsa fishermen of Ramgati. 


\begin{tabular}{|c|c|c|}
\hline Food items & Fishing season (days/month) & Banning season (days/month) \\
\hline Vegetables & 30 & 30 \\
\hline Fish & 9 & 0 \\
\hline Meat & 2 & 0 \\
\hline Egg & 8 & 5 \\
\hline Milk & $13 \%$ respondent & $7 \%$ respondent \\
\hline
\end{tabular}

Table 2: Food taken by the fishermen of Ramgati upazila during fishing and banning season.

\section{Educational status}

Hilsa fishers were categorized into four based on their level of education. Out of 150 fishermen of Meghna river of Ramgati upazila, 24\% had no education (illiterate), $49 \%$ can only sign, $20 \%$ had primary level (class $1-5$ ) and 7\% had secondary level (class 6-10) of education (Table 1). It can be said that majority of the fishermen were either illiterate or only can sign because most of the sampled fishermen were compelled to earn from fishing profession in their early stage due to poor economic status of their parents and lack of awareness about education. Another important factor was that educational institutions needed in the areas of fishing villages were not sufficient.

\section{Drinking water and sanitary facilities}

The study showed that all of the hilsa fishermen (100\%) households used tube-well water for drinking purposes. Among them $9 \%$ fishermen used their own tube-well, $27 \%$ used government tube-well, $60 \%$ used neighbors and remaining used community tube-well (Figure 1). This scenario was very common among the fishermen in most areas of Bangladesh and similar results were noted by other authors [10-13].

In the studied area, it was found that majority (137) of the respondents had katcha (earthen) toilet and 13 respondents had semi-pacca (semicemented) toilet. Fishermen were not aware due to lack of knowledge on health and environment, less income etc [14]. Poor sanitation system reflects poor socio-economic condition and lower income.

\section{Food taken by the fishermen}

Fishermen were found to work hard all day long to manage their food. In spite of such heavy labour they were found to be the poorest community suffering from the scarcity of daily bread. During the study it was found that vegetables were the most common food item in every fisher's family. They had little fish (average 9 days per month and no fish during banning period) and egg (average 8 days per month and 5 days during ban period) to eat. They took very little meat (average 2 days per month but no chance during ban period). Only $13 \%$ fishermen had facility to take milk (average 5 days per month) and only $7 \%$ fishermen took average 6 days per month during ban period (Table 2). Similar findings were also reported by Kostori [15]

\section{Experience in Fishing}

The average experience in fishing was found 18 years (1998-2016) in the current study where the minimum was 3-years (2013-2016) and maximum was 40 years (1976-2016). Islam et al., found that the mean experience in fishing was $17.9 \pm 7.12$ years [16].

\section{Fishing Duration}

In the study area all fishermen were reported to go for fishing during both day and night. The average fishing duration recorded was 15 hour/ day. They usually go for fishing in peak season which was average 19 days/month that reduced to an average 9 days/month in off season.

\section{Fishing assets}

The present findings showed that 33\% fishermen had their own boats and nets. Most of the hilsa fishermen (67\%) worked with other fishers who possessed fishing gears and boat but surprisingly no fishermen were found under joint collaboration with other fishers (Figure 2). In his study Alam et al., found almost similar results [10].

\section{Occupation status}

All respondents reported fishing is their primary occupation and highest total income (89\%) source. However, primary occupation could not afford full time employment and the income derived therefore might be insufficient to supply adequate means of livelihood. Several types of secondary occupations were recorded. The most common secondary occupation was PL collection $29 \%$, labour $11 \%$, agriculture $15 \%$, fish culture $2 \%$, business $7 \%$ and $36 \%$ had no other job source (Figure 3).

During the banning season fishermen seek alternative income opportunities and involved in various occupations as migrate to town $11 \%$, boat and net making $24 \%$, agricultural works $36 \%$, rickshaw pulling $2 \%$ and remaining $27 \%$ without work (Figure 4 ) which was similar to the findings of Alam and Bashar [17].

\section{Income level and expenditure of hilsa fishermen}

Level of income of an individual family determines socio-economic status in a society. In most cases the income of the fishermen in Bangladesh is below poverty level [18]. During study period it was observed that the highest (44\%) and the second highest number (31\%) of the fishers' annual income ranged between 21,000-40,000 and $41,000-60,000$ BDT respectively. The highest and the lowest 100,000 and 20,000 BDT was earned annually by $5 \%$ and $2 \%$ of the fishers. Ali et al., also reported the similar findings [19]. The major expenditures of a household were found as in food, health, cloths, education, maintenance of housing and telecommunications etc.

\section{Credit access}

The survey evidences that majority of fishermen (93\%) took loan but the institutional credit facilities were very limited for the fishermen community. The poor fishermen took loan from boat owners or mahajon $(33 \%)$ where they bound to work round the year. On the other hand, the boat owners took loans from aratdar or dadondar (24\%) where they had to repay the loan selling the fish to the aratdar in their fixed price and commission rates and fishers were restricted from selling their catch to open market. They also took loan from NGOs (31\%), Banks (2\%) and other sources (10\%) with high interest rate (Figure 5). In a study by Zaman et al., it was revealed that poor fish farmers had no access to bank loan due to lack of mortgage assets [20]. Hilsa fishermen usually 


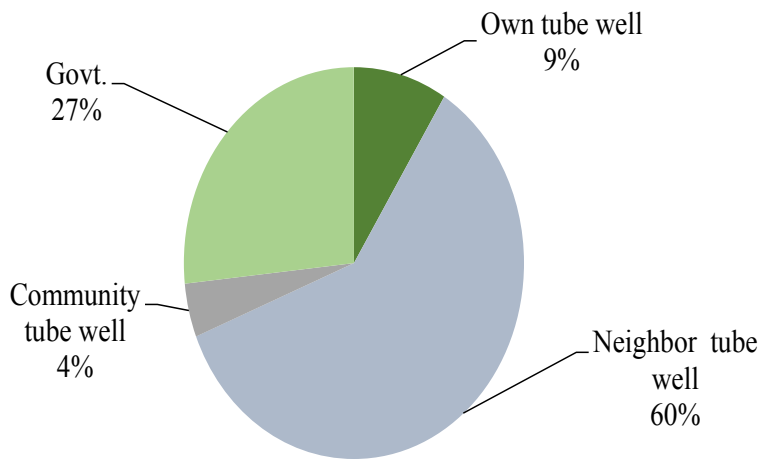

Figure 1: Drinking water facilities enjoyed by the fishermen in the study area.

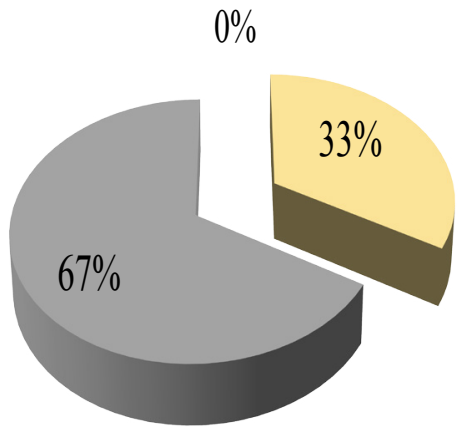

Own boat and net

work in others' boat

joint ownership boat

Figure 2: Fishing assets of the studied fishermen.

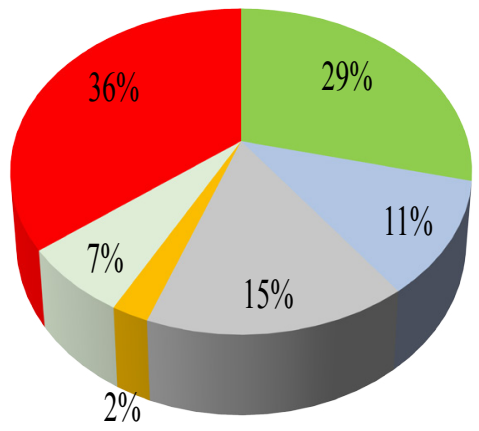

—PL collection

Labour

$\square$ Agriculture

-Fish culture

Bussiness

-No other jobs

Figure 3: Secondary occupation of fishermen of Ramgati upazila.

took loan for boat construction and net buying, to meet the payment of boat labour, for marriage and dowry, for food and medicine, for natural disaster and repayment of previous loans etc.

\section{Livelihood constraints and vulnerability context}

The fishers of the study area encountered many constraints in maintaining livelihood activities. The main constraints were burden of dadon, market controlled by aratder/bapari, poor market facilities, reduction in fish catches in the recent years, loss of fishing equipment especially nets and boats during fishing to the $53 \%, 89 \%, 9 \%, 9 \%$ and $56 \%$ respectively. These types of problems were also being faced by the fishermen elsewhere $[2,18,21]$. In recent years, piracy in the fishing areas becomes a major problem for the $91 \%$ fishers. Pirates abducted fishers for ransom, looted fish catch and fishing accessories, sometime
-Migrate to town $\square$ Boat \& net making agricultural activities $\square$ Riksha Pulling $\square$ no work

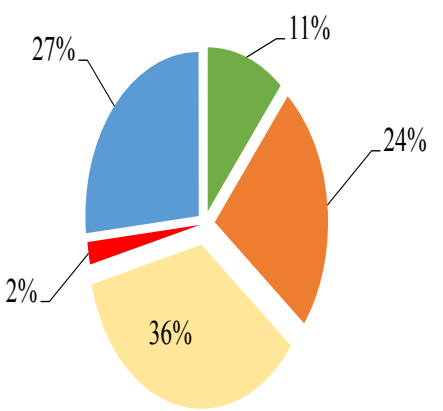

Figure 4: Alternative income sources of fishers during banning season.

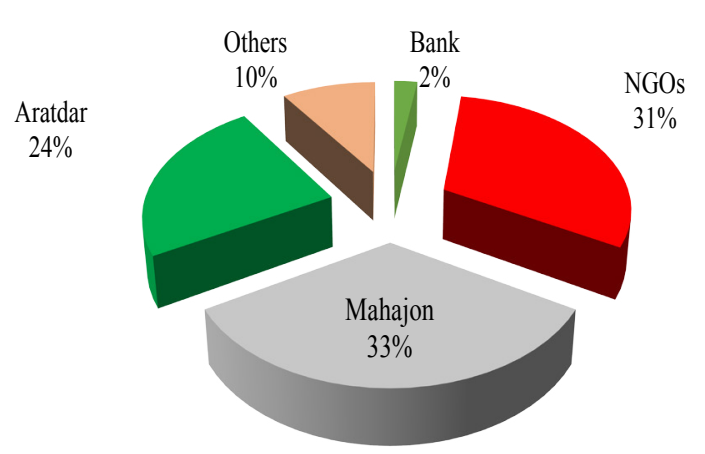

Figure 5: Sources of loan or dadon taken by the hilsa fishermen in Ramgati upazila.

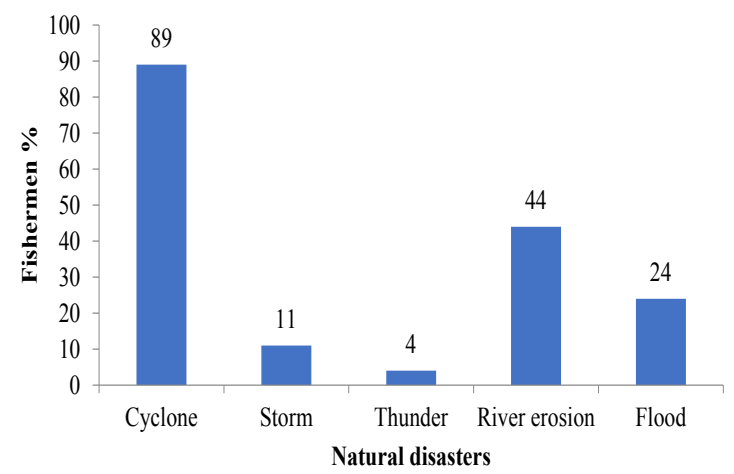

Figure 6: Problems faced by Hilsa fishermen in Ramgati upazila during natural disasters.

injured or killed the fishers. Kleih et al., showed that piracy is very rampant in the Chittagong, Cox's Bazar and Patuakhali coasts, and almost daily the fishers along this coastline are facing the act of piracy of their fishing gears and catches in the sea [22]. Day by day increasing price and unavailability of fishing materials like boat, net, ice were main fishing constraints for fishermen. Sometimes they could not go to the river with boat and net for insufficient capital. $89 \%, 11 \%, 4 \%, 44 \%$ and $24 \%$ fishermen faced natural disasters like cyclone, storm, thunder, river erosion and flood respectively (Figure 6).

\section{Status of current livelihood}

Livelihood outcomes can be thought of as the inverse of poverty. 
Citation: Rana MEU, Salam A, Shahriar Nazrul KM, Hasan M (2018) Hilsa Fishers of Ramgati, Lakshmipur, Bangladesh: An Overview of Socio-Economic and Livelihood Context. J Aquac Res Development 9: 541. doi: 10.4172/2155-9546.1000541

Contributing to the eradication of poverty and food security depends on equitable access to the resources, access of disadvantaged group to sufficient, safe and nutritionally adequate food [23]. From the survey it was revealed that $54 \%$ fishermen (though they get benefit from government during banning period) improved their livelihood status through fishing where $46 \%$ fishermen had not yet improved their status. Similar results also reported by Halder et al. [24]. Livelihood outcome factors are food security, nutrition, health, income, education, housing facilities, environment, safety etc.

\section{Conclusion}

The socio-economic conditions of fishermen of Ramgati upazila were not satisfactory. Fishers were found to be mostly poor, landless and neglected in the society and are exploited by the rich people/ mahajan/aratdar in different ways. Population pressure, low income, lack of alternative employment opportunities, extortion by the local extortionist, loan problems, piracy etc. were the common socioeconomic constraints to the fishermen of the study area. Government support to the affected fishers during ban period is quite insufficient and is not properly distributed. Urgent steps from the government, NGOs and donor agencies should be taken to provide alternate livelihood support as well as job creation to the hilsa fishers especially during ban and lean period.

\section{References}

1. Do F (2017) National Fish Week 2017 Compendium (In Bengali). Department of Fisheries, Ministry of Fisheries and Livestock, Bangladesh, p: 160.

2. Halder DK (2002) Studies on the availability of small indigenous species (SIS) of fishes and socio-economic condition of fishers in two rice fields. MS Thesis, Department of Fisheries Management, Bangladesh Agricultural University Mymensingh, p: 136

3. Do F (2007) Fishery statistical yearbook of Bangladesh 2005-2006. Fisheries Resources Survey System, Department of Fisheries (DOF), Ministry of Fisheries and Livestock, Dhaka, Bangladesh.

4. Sazzad A (1993) An economic study of Hilsa fishing in the river Meghna in Chandpur district MS Thesis, Department of Agricultural Economics, Bangladesh Agricultural University, Mymensingh.

5. Moula G, Mahmud Y, Alam MG, Hossain MA (1993) Fishing crafts and gears of the Meghna River. Progress Agric 4: 59-65.

6. Ahmed N (1954) Fishing gears of East Pakistan. Pak J Sci 6: 162-178.

7. Akram M (2008) Study on socio-economic condition of fishermen of the Jamuna River in Dewangonj upazila. MS Thesis, Department of Fisheries Management, Bangladesh Agricultural University, Mymensingh.

8. Bhaumik U, Saha SK (1994) Perspectives on socio-economic status of the fishermen engaged in fishing in the estuaries of Sundarbans. J Ecol 12: 181 185.
9. Minar MH, Rahman AFMA, Anisuzzaman M (2012) Livelihood status of the fisherman of the Kirtonkhola River nearby to the Barisal town. J Agrofor Environ 6: 115-118.

10. Alam MS, Flowra FA, Salam MA, Kabir AKMA, Ali H (2009) Fishing gears, fish marketing and livelihood status of the poor fishermen around the Basantapur beel at lalpur upazila. J Agrofor Environ 5: 91-97.

11. Rahman M, Rahman MM, Hasan MM, Islam MR (2012) Livelihood status and the potential of alternative income generating activities of fisher's community of Nijhum Dwip under Hatiya Upaliza of Noakhali district in Bangladesh. J Bangla Res Pub 6: 370-379.

12. Abdullah-Bin-Farid BMS, Mondal S, Satu KA, Adhikary RK, Saha D (2013) Management and socio-economic conditions of fishermen of the Baluhar Baor Jhenaidah, Bangladesh. J Fish 1: 30-36.

13. Kabir KMR, Adhikary RK, Hossain MB, Minar MH (2012) Livelihood status of fishermen of the old Brahmaputra River, Bangladesh. World Appl Sci J 16: 869873.

14. Rabbani MG (2007) Fisheries and socio-economic condition of fishermen of Karatoa River. MS Thesis, Department of Fisheries Management, Bangladesh Agricultural University, Mymensingh.

15. Kostori MFA (2012) Socio-economic condition of fishermen of the Chalan bee under Tarash Thana of Sirajganj district in Bangladesh. J Bangla Res Pub 6: 393-402.

16. Islam MR, Galib SM, Rahman MA (2013) Livelihood of the fishermen in Monirampur Upazila of Jessore district, Bangladesh. J Fish 1: 37-41.

17. Alam MF, Bashar MA (1995) Structure of cost and profitability of small scale riverine fishing in Bangladesh. J Bangla Agri Univ 9: 235-241.

18. Hossain MM (2007) Utilization pattern of Mokash beel for livelihood of the loca fishermen of Kaliachoir upazila under Gazipur district. MS Thesis, Department of Aquaculture, Bangladesh Agricultural University, Mymensingh.

19. Ali H, Azad MAK, Anisuzzaman M, Chowdhury MMR, Hoque M, et al. (2009) Livelihood status of the fish farmers in some selected areas of Tarakanda upazila of Mymensingh district. J Agrofor Environ 3: 85-89.

20. Zaman T, Jewel MAS, Bhuiyan AS (2006) Present status of pond fishery resources and livelihood of the fish farmers of Mohanpur upazila in Rajshah District. Univ j zool Rajshahi Univ 25: 31-35.

21. Alam MS (2004) Gender role and gender participation in beel fishery in some selected area in Gazipur sadar under Gazipur district. MS Thesis, Department of Fisheries Management, Bangladesh Agricultural University, Mymensingh.

22. Kleih U, Alam K, Dastidar R, Dutta U, Oudwater N, et al. (2003) Livelihoods in coastal fishing communities, and the marine fish marketing system of Bangladesh, NRI report NO: 2712, National Resources Institute (NRI) Greenwich University, London.

23. Scoones I (1998) Sustainable rural livelihoods: A framework for analysis. IDS working paper No. 72, Brighton: IDS, UK p: 20.

24. Halder P, Ali H, Gupta N, Aziz MSB, Monir MS (2011) Livelihood status of fresh fish, dry fish and vegetable retails at Rajoir Upazila of Madaripur district Bangladesh. J Bangla Res Pub 5: 262-270. 